\title{
Functional Evaluation Tests as Prognostic Factors of Falls in Elderly Patients
}

\author{
(1) Javier Benítez1, (1) Juan Manuel Ignacio'1, (1) Sofía Perea33, (1) José Antonio Girón² \\ 'La Laguna Health Center, Department of Internal Medicine, Cádiz, Spain \\ 2 Puerta del Mar University Hospital, Clinic of Internal Medicine, Cádiz, Spain \\ ${ }^{3}$ Beth Israel Deaconess Medical Center, Department of Medicine, Boston/MA, USA
}

\begin{abstract}
Objective: Analysis of risk factors for falls through a detailed geriatric evaluation is essential. The aim of the present study was to analyze prognostic factors for falls in elderly patients in Spain.

Materials and Methods: a) Initial phase ( $n=247)$ : transverse observational study. Inclusion criteria: patients >80 years old living alone and/or with a relative of similar age; b) Final phase ( $n=90)$ : prospective cohort study of the previously enrolled patients. Variables analyzed included demographics; clinical characteristics and results of timed up and go (TUG) (mobility assessment) and Lobo (cognitive assessment) tests; Lawton-Brody Instrumental Activities of Daily Living scale and Barthel index (basic activities).

Results: Falls were significantly associated with changes in Lobo and Barthel test results during both phases. No association was found between falls and comorbidities, number or type of treatment received and analytical variables studied. No statistical difference was observed in TUG test between fallers and non-fallers in the initial phase. A significant deterioration was observed in Lobo, Lawton-Brody, Barthel and TUG evaluation tests during the 4-year in between-period; male gender and a lower score in Lobo test were independent variables related to mortality. In the final phase, a TUG cut-off value of 25 seconds (sensitivity=0.52; specificity=0.75), that differentiated fallers from non-fallers, was established.
\end{abstract}

Conclusion: Tests that evaluate cognitive ability and functional activities are predictors of falls in the elderly. The use of Lobo test to define the cognitive state of elderly patients may contribute to predict their vital prognoses.

Keywords: Elderly, fall, risk of fall, time get up and go test, Lobo test, Lawton-Brody test, Barthel test

\section{Introduction}

Falls in elderly patients are a daily concern that occurs in almost half of them, with a wide range of consequences and whose importance is not recognized neither by themselves, nor their relatives, nor health professionals $(1,2)$. They are seldom accidental, but rather the result of an inadequacy between the senior and his/her surroundings; hence the unawareness of the risk factors associated with the falls contributes to an increase in their incidence (3).

Extrinsic (environmental) as well as intrinsic (clinical factors) risk factors associated with falls have been previously described $(4,5)$. The incidence of falls increases progressively with age, reaching $50 \%$ in individuals $>80$ years $(6,7)$. A study conducted by our group established that the incidence of falls in individuals $>80$ years per number of patients/year ranged between 11.9\% and $17.8 \%$, with a mean value of $14.0 \%(6,8,9)$.

The analysis of the risk factors associated with falls through a geriatric assessment is a key element for their adequate management. Such assessment should include a multidimensional analysis $(10,11)$ : a) circumstances of the fall; b) comprehensive geriatric valuation: b1. biological evaluation (acute or chronic processes, as well as drug consumption, nutritional status, presence of other geriatric syndromes); b2. functional evaluation (Barthel and Lawton-Brody tests) (11,12); b3. Mental and psycho-affective evaluations (minimental state examination, or Lobo test (13), as well as depression scale);

Address for Correspondence: Javier Benitez, La Laguna Health Center, Department of Internal Medicine, Cádiz, Spain

E-mail: pipelinebiomedicalresources@hotmail.com ORCID: orcid.org/0000-0001-5541-1585

Received: Jul 27, 2019 Accepted: Oct 19, 2019

Cite this article as: Benitez J, Ignacio JM, Perea S, Giron JA. Functional Evaluation Tests as Prognostic Factors of Falls in Elderly Patients. Eur J Geriatr Gerontol 2019;1(3):78-86

๑Copyright 2019 by the Academic Geriatrics Society / European Journal of Geriatrics and Gerontology published by Galenos Publishing House. 
b4. Social assessment (presence/absence of caregiver, housing situation, social relationships); c) evaluation of cardiovascular, neurological and musculoskeletal systems; d) ophthalmological examination; $\mathrm{e}$ ) assessment of balance and gait; $\mathrm{f}$ ) environmental assessment; g) specific complementary examinations: blood count, glycemia, ions, thyroid hormones, vitamin D, EKG, among others.

With regards to the assessment of balance and gait, although the Tinetti test was initially validated to predict the risk of falls, however, in daily clinical practice the test timed up and go (TUG) is currently used (14). This test presents a high correlation with the speed of the march, it is much easier to carry out, requires less time and has a strong correlation with Tinetti test $(15,16)$.

In 2009 the "Comprehensive Plan for elderly individuals $\geq 80$ years of age who live alone and/or with a relative with a similar age" was implemented in our center. The results of a preliminary study showed that: a) the most common locations of falls are corridor, bathroom, living room, bedroom and elevators; b) the risk of falls increases with the degree of dependence; c) The degree of dependence correlates with the results of the TUG test.

Based on those results, the present study was designed to analyze the frequency and factors involved (including the TUG, Lobo, Lawton-Brody and Barthel tests) in the risk of falls in elderly patients living alone and/or with a relative of similar age in the province of Cádiz, Spain.

\section{Materials and Methods}

\section{Study Design}

The study was conducted in Unidad de Gestión Clínica "La Laguna", Cadiz, Spain and was approved by the relevant health authorities and ethic committees. The study consisted of an initial phase (2013) and a final phase (2017): a) Initial phase: transverse observational study. Inclusion criteria: Patients $>80$ years living alone and/or with a relative of similar age. Those in whom the TUG test could not be carried out due to neurological alterations, trauma or rheumatic diseases were excluded from the final phase of the study; b) Final phase: prospective cohort study of the patients enrolled in 2013, followed until 2017. The electronic medical records were reviewed and once the cases were selected, patients were visited in their homes, and after obtaining the informed consent, collection of variables and performance of tests described below were performed.

\section{Study Outcomes}

1. Primary outcome: To analyze factors (Lobo, Lawton-Brody, Barthel and TUG tests) involved in the development of falls in patients $>80$ years old years living alone and/or with a relative of similar age. Tests were conducted by primary care physicians.
In particular, the following specific outcomes were studied:

a) Analysis of the frequency of falls

b) Establishment of the intrinsic risk factors associated with a higher frequency of falls.

c) Establishment of the predictive value of TUG test in the appearance of falls.

d) Association between cognitive level (Lobo test) and risk of falls.

e) Association between falls and the outcome regarding cognitive assessment (Lobo test), instrumental (Lawton-Brody tests) and basic (Barthel test) daily activities.

2. Secondary outcomes: Correlation between the levels of vitamin $D$ and frequency of falls among elderly patients and predictive value of death of Lobo, Lawton-Brody, Barthel and TUG tests.

\section{Variables Analyzed}

1. Dependent variables: Number of falls; number of deaths.

2. Independent variables: a) demographic (gender, age); b) Clinical characteristics: b.1) comorbidities: cardiological; neurological; respiratory; musculoskeletal system); metabolic/ endocrine diseases; b.2) biochemistry values: hemoglobin; glycemia; glycated hemoglobin (HbA1c)(\%); iron; ferritin; transferrin; vitamin B12; folic acid; total proteins; albumin; thyroid stimulating hormone (TSH); cholesterol; triglycerides; uric acid; creatinine; vitamin $D$ (this latter only during final phase); c) functional evaluation tests: Lobo, TUG, Barthel and Lawton-Brody tests; d) drug treatments associated with a greater risk of falls (only during final phase).

\section{Instruments}

1. TUG Test: Validated test in which the patient is time while they rise from a chair, walk $3 \mathrm{~m}$, turn around, return to the chair, and sit down again. A faster time indicates a better functional performance. Reported threshold values vary from 10 to 33 seconds (17).

2. Lobo Test (Mini Examen Cognoscitivo): It is the Spanish validation/adaptation of the Folstein minimental state examination (MMSE), and consists of 35 items, and each correct answer is scored as 1 point. It evaluates six cognitive abilities (orientation, registration, attention and concentration, short-term memory and language), and takes 5-10 minutes to administer. The cutting point of advanced cognitive impairment stands at 24/35 points. The test has a sensitivity for diagnosis of $90.7 \%$ and a specificity of $69 \%$ (18).

3. Lawton-Brody Test: It is a validated instrument to assess independent living skills. There are eight domains of function measured with the Lawton IADL scale. A summary score 
ranges from 0 (low function, dependent) to 8 (high function, independent) for women, and 0 through 5 for men (19).

4. Barthel Index: The Barthel index is a validated test that encompasses 10 items on motor tasks rated on a weighted ordinal scale with lower scores indicating more need for assistance to complete each activity. The maximum score is 100 points (90 if the patient is travelling in a wheelchair). The cutoff points are: a) 81-100, self-employed; b) 61-80, mild dependence; c) 46-69, moderate dependence, and $d)<45$, severe dependence $(20,21)$.

\section{Statistics}

For quantitative variables that follow a normal distribution (analyzed by Kolmogorov-Smirnov test), mean and the standard deviation were used; otherwise, median and interquartile range. Qualitative variables were expressed by number and percentage. Student's t-test was used for comparison of two means in case of parametric quantitative variables and with homogeneous variances, otherwise, MannWhitney U test was used. Qualitative variables were compared using the chi-square test, with Fisher correction whenever needed. The ROC curve of the TUG test, its positive and negative predictive values, as well as the establishment of a cut-off to determine the risk of falls was determined during the final phase. For the evaluation of the independent association of risk factors for falls and mortality, a logistic regression test was carried out, introducing in the model those factors that had reached statistical significance in the bivariate analysis. For data analysis, SPSS statistical package, version 20.0 (SPSS Inc. Chicago, IL, USA) was used. A level of significance of $95 \%$ $(p<0.05)$ was considered.

\section{Results}

\section{Initial Phase}

During the years 2013-2017, a total of 342 that patients fulfilled all the inclusion criteria, from a pool population of 984 patients, were selected. Of those, 247 signed the informed consent and were enrolled in the initial phase of the study. The demographic and clinical characteristics as well as the frequency of falls are summarized in Table 1. The most common comorbidities were hypertension and rheumatic diseases, followed by diabetes mellitus and were not significantly associated with a higher risk of falls $(p>0.005)$. With regards to functional evaluation tests, the profile of the elderly patient in this initial phase showed an acceptable cognitive level, with autonomy for the basic and instrumental daily life activities. Statistical significant differences were observed between those who have reported falls vs those who have not, with regards to cognitive level (Lobo test) and daily basic activities (Barthel test). As of TUG score, no significant difference was observed between
Table 1. Initial and final phases: demographic and clinical characteristics

\begin{tabular}{|l|c|c|}
\hline Demographics & $\begin{array}{c}\text { Baseline phase } \\
(\mathbf{n}=\mathbf{2 4 7})\end{array}$ & $\begin{array}{c}\text { Final phase } \\
(\mathbf{n}=\mathbf{9 0})\end{array}$ \\
\hline Gender (n, \%M/F) & $247(30.8 \% / 69.2 \%)$ & $90(17.7 \% / 82.3 \%)$ \\
\hline $\begin{array}{l}\text { Age, mean (range), } \\
\text { in years }\end{array}$ & $89.2 \pm 3.6(80-101)$ & $88.9 \pm 2.6(83-96)$ \\
\hline Age ranges: $\mathbf{n}($ \%) & \\
\hline
\end{tabular}

Age ranges: $\mathbf{n}(\%)$

\begin{tabular}{|l|c|c|}
\hline $80-84$ & $152(61.5 \%)$ & $4(4.4 \%)$ \\
\hline $85-89$ & $75(30.4 \%)$ & $57(63.3 \%)$ \\
\hline$\geq 90$ & $20(8.1 \%)$ & $29(32.2 \%)$ \\
\hline
\end{tabular}

Falls $(\mathrm{n}, \%)$

\begin{tabular}{|l|c|c|}
\hline No & $65(26.3 \%)$ & $67(74.4 \%)$ \\
\hline Yes & $182(73.7 \%)$ & $23(25.5 \%)$ \\
\hline
\end{tabular}

Comorbidities (n, \%)

\begin{tabular}{|c|c|c|}
\hline Hypertension & $128(51.8 \%)$ & $42(46.7 \%)$ \\
\hline Diabetes mellitus & $51(20.6 \%)$ & $18(20.0 \%)$ \\
\hline $\begin{array}{l}\text { Rheumatological } \\
\text { diseases }\end{array}$ & $61(24.7 \%)$ & $25(27.8 \%)$ \\
\hline Cognitive impairment & $23(9.3 \%)$ & $3(3.3 \%)$ \\
\hline Digestive disease & $10(4.0 \%)$ & $16(17.8 \%)$ \\
\hline Hyperlipidemia & $7(2.8 \%)$ & $16(17.8 \%)$ \\
\hline Cardiopathy & $5(2.0 \%)$ & $7(7.8 \%)$ \\
\hline Renal disease & $5(2.0 \%)$ & $4(4.4 \%)$ \\
\hline Stroke & $4(1.6 \%)$ & $9(10.0 \%)$ \\
\hline $\begin{array}{l}\text { Chronic obstructive } \\
\text { pulmonary disease }\end{array}$ & $1(0.4 \%)$ & $3(3.3 \%)$ \\
\hline Others* & $23(9.3 \%)$ & $10(11.1 \%)$ \\
\hline \multicolumn{3}{|c|}{ Biochemistry (mean \pm SD) } \\
\hline Hemoglobin $(\mathrm{g} / \mathrm{dL})$ & $13.1 \pm 1.5$ & $13.2 \pm 1.5$ \\
\hline Glycemia (mg/dL) & $112.8 \pm 42.4$ & $111.5 \pm 31.0$ \\
\hline $\mathrm{HbA}_{1 \mathrm{c}}(\%)$ & $6.9 \pm 1.9$ & $6.6 \pm 1.1$ \\
\hline Iron $(\mu \mathrm{g} / \mathrm{dL})$ & $69.1 \pm 26.5$ & $75.6 \pm 28.3$ \\
\hline Ferritin (ng/dL) & $81.3 \pm 65.7$ & $79.4 \pm 63.6$ \\
\hline Transferrin (mg/dL) & $274.1 \pm 55.5$ & $276.9 \pm 49.4$ \\
\hline Vitamin $B_{12}(p g / d L)$ & $427.2 \pm 277.9$ & $435.7 \pm 282.2$ \\
\hline Folic acid $(\mathrm{ng} / \mathrm{mL})$ & $12.1 \pm 12.4$ & $12.1 \pm 12.3$ \\
\hline Total proteins (g/dL) & $6.9 \pm 0.6$ & $7.1 \pm 0.6$ \\
\hline Albumin (g/dL) & $4.5 \pm 3.9$ & $5.3 \pm 3.1$ \\
\hline TSH (ng/dL) & $3.1 \pm 2.1$ & $3.1 \pm 2.2$ \\
\hline Cholesterol (mg/dL) & $202.2 \pm 40.8$ & $208.9 \pm 47.5$ \\
\hline Triglycerides (mg/dL) & $124.2 \pm 71.3$ & $122.7 \pm 57.3$ \\
\hline Uric acid (mg/dL) & $5.2 \pm 1.6$ & $5.1 \pm 1.2$ \\
\hline Creatinine $(\mathrm{mg} / \mathrm{dL})$ & $1.1 \pm 0.6$ & $0.9 \pm 0.4$ \\
\hline
\end{tabular}




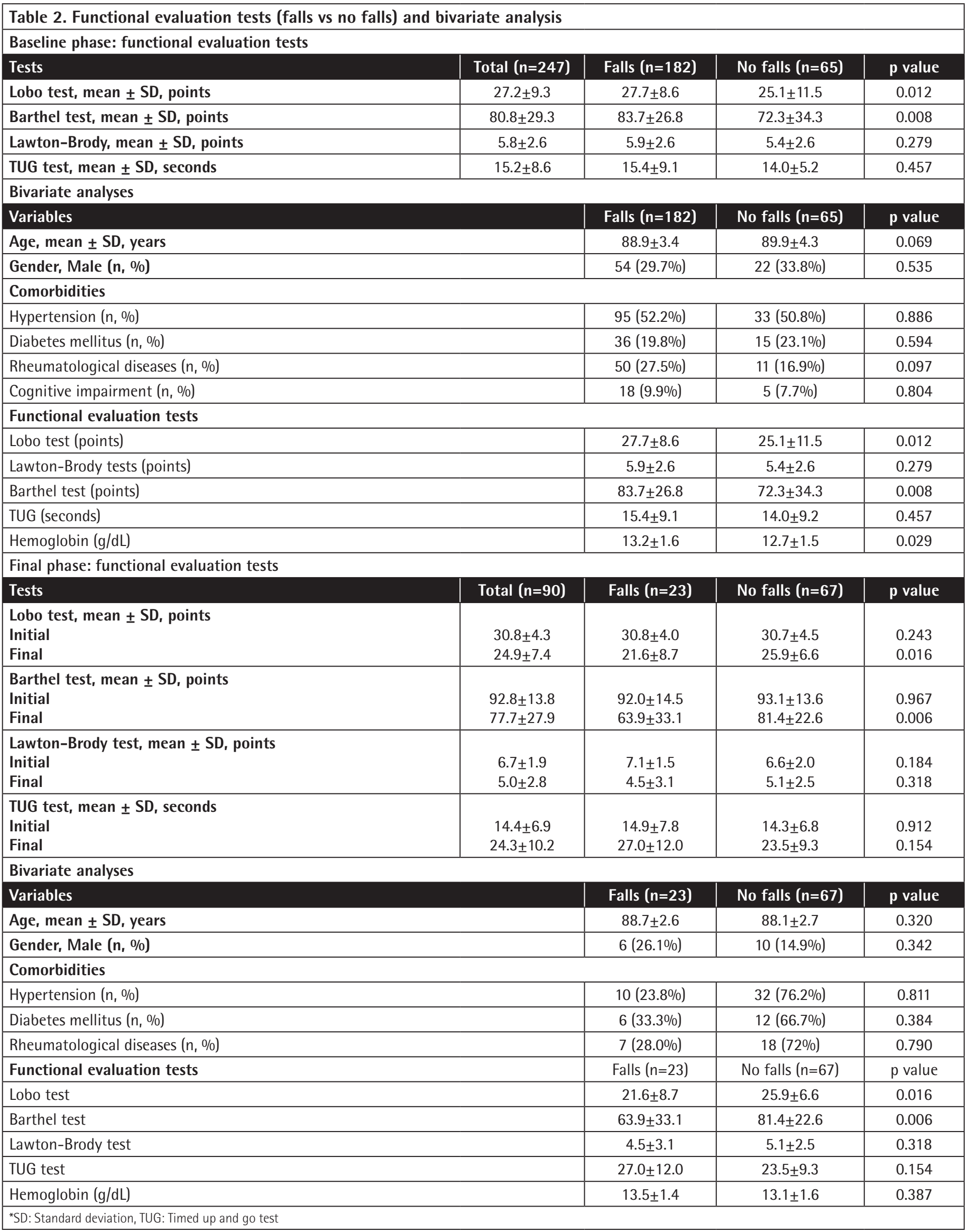




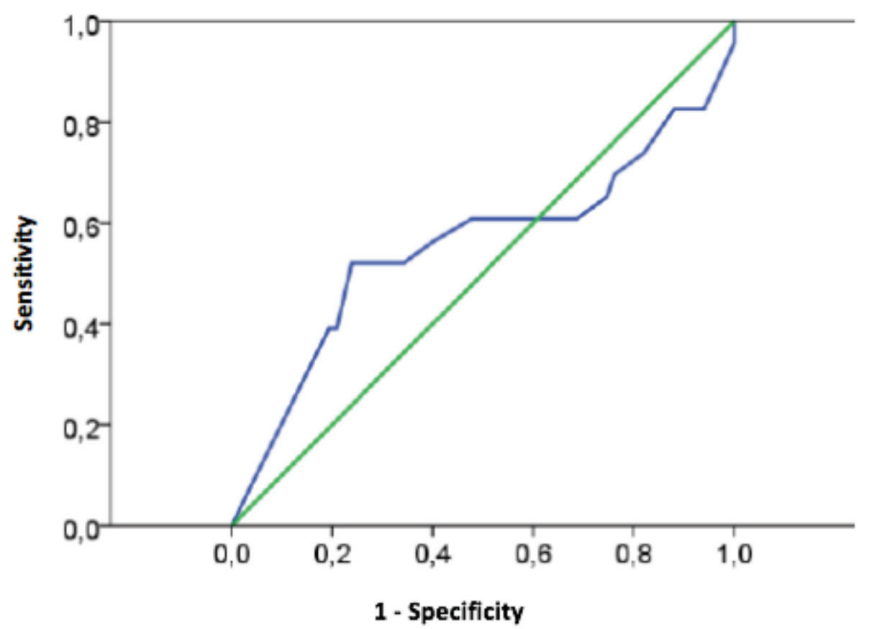

Area Under the Curve (AUC)

\begin{tabular}{|l|l|l|l|l|}
\hline Area & Typical & $\begin{array}{l}\text { Asymptotic } \\
\text { error } \\
\text { significance }\end{array}$ & & \begin{tabular}{l} 
95\% Asymptotic CI \\
\cline { 4 - 5 }
\end{tabular} \\
& & $\begin{array}{l}\text { Lower } \\
\text { limit }\end{array}$ & Upper limit \\
\hline 0.555 & 0.80 & 0.432 & 0.398 & 0.713 \\
\hline
\end{tabular}

CI: Confidence Interval

\begin{tabular}{|l|l|l|l|}
\hline & No falls (n=67) & Falls (n=23) & p value \\
\hline $\begin{array}{l}\text { TUG } \geq 25 \text { seconds } \\
(\mathrm{n}, \%)\end{array}$ & $18(26.9 \%)$ & $12(52.2 \%)$ & 0.039 \\
\hline
\end{tabular}

Figure 1. TUG test: ROC curve

TUG: Timed and go test, ROC: Receiver operating characteristic the mean value of the fallers vs non-fallers (Table 2). A significant positive correlation between age and TUG was detected, whereas a negative correlation was found between age and Lobo, Lawton-Brody and Barthel tests, respectively (Table 3). Lobo, Lawton-Brody and Barthel tests correlated significantly with each other and negatively with TUG. Previous falls was significantly associated with a higher score in Lobo and Barthel tests as well as with a significantly higher concentration of hemoglobin (Table 2).

\section{In Between Phase}

Between the two phases, 108 individuals (43.7\% of the 247 subjects who participated in the initial phase) died; 24 (9.7\%) changed residence, $17(6.8 \%)$ were admitted in nursing homes and eight (3.2\%) withdrew informed consent. Among the deceased, no primary or secondary-related disease associated with falls was detected. The causes of the deaths included: cardiovascular disease $(n=32,30.2 \%)$; cancer $(n=25,23.3 \%)$; cognitive disorder ( $\mathrm{n}=17$ individuals, 15.1\%); cerebrovascular disease $(n=13,11.8 \%)$; respiratory disease $(n=9,7.7 \%)$; gastrointestinal disease $(n=8,7.3 \%)$; diabetes mellitus $(n=3$, $7.3 \%)$ and renal disease $(n=1,2.1 \%)$. The deceased were slightly older than the survivors; the proportion of males was higher; Lobo, Lawton-Brody and Barthel tests' scores were lower and had lower cholesterol concentrations. No significant differences were observed regarding the presence of previous falls or the

\begin{tabular}{|c|c|c|c|c|c|c|}
\hline \multicolumn{2}{|l|}{ Initial phase } & Age & Lobo test & Barthel test & Lawton test & TUG test \\
\hline Age & $\begin{array}{l}R \text { value } \\
p \text { value }\end{array}$ & $\begin{array}{l}1 \\
-\end{array}$ & $\begin{array}{c}-0.190 \\
0.008\end{array}$ & $\begin{array}{c}-0.207 \\
0.001\end{array}$ & $\begin{array}{c}-0.282 \\
0.000\end{array}$ & $\begin{array}{l}0.306 \\
0.000\end{array}$ \\
\hline Lobo test & $\begin{array}{l}R \text { value } \\
p \text { value }\end{array}$ & $\begin{array}{c}-0.190 \\
0.008\end{array}$ & $\begin{array}{l}1 \\
-\end{array}$ & $\begin{array}{l}0.779 \\
0.000\end{array}$ & $\begin{array}{l}0.662 \\
0.000\end{array}$ & $\begin{array}{c}-0.453 \\
0.000\end{array}$ \\
\hline Barthel test & $\begin{array}{l}R \text { value } \\
p \text { value }\end{array}$ & $\begin{array}{c}-0.207 \\
0.000\end{array}$ & $\begin{array}{l}0.779 \\
0.000\end{array}$ & $\begin{array}{l}1 \\
-\end{array}$ & $\begin{array}{l}0.768 \\
0.000\end{array}$ & $\begin{array}{c}-0.576 \\
0.000\end{array}$ \\
\hline Lawton test & $\begin{array}{l}R \text { value } \\
p \text { value }\end{array}$ & $\begin{array}{c}-0.282 \\
0.000\end{array}$ & $\begin{array}{l}0.662 \\
0.000\end{array}$ & $\begin{array}{l}0.768 \\
0.000\end{array}$ & $\begin{array}{l}1 \\
-\end{array}$ & $\begin{array}{c}-0.560 \\
0.000\end{array}$ \\
\hline TUG test & $\begin{array}{l}R \text { value } \\
p \text { value }\end{array}$ & $\begin{array}{l}0.306 \\
0.000\end{array}$ & $\begin{array}{c}-0.453 \\
0.000\end{array}$ & $\begin{array}{l}-0.576 \\
0.000\end{array}$ & $\begin{array}{c}-0.560 \\
0.000\end{array}$ & $\begin{array}{l}1 \\
-\end{array}$ \\
\hline Final phase & & TUG test & Lobo test & Barthel test & Lawton test & Vitamin D \\
\hline TUG test & $\begin{array}{l}R \text { value } \\
p \text { value }\end{array}$ & $\begin{array}{l}1 \\
-\end{array}$ & $\begin{array}{c}-0.474 \\
0.000\end{array}$ & $\begin{array}{c}-0.758 \\
0.000\end{array}$ & $\begin{array}{c}-0.758 \\
0.000 \\
\end{array}$ & $\begin{array}{c}-0.259 \\
0.014\end{array}$ \\
\hline Lobo test & $\begin{array}{l}R \text { value } \\
p \text { value }\end{array}$ & $\begin{array}{c}-0.474 \\
0.000\end{array}$ & $\begin{array}{l}1 \\
-\end{array}$ & $\begin{array}{l}0.660 \\
0.000\end{array}$ & $\begin{array}{l}0.683 \\
0.000\end{array}$ & $\begin{array}{l}0.262 \\
0.013\end{array}$ \\
\hline Barthel test & $\begin{array}{l}R \text { value } \\
p \text { value }\end{array}$ & $\begin{array}{c}-0.758 \\
0.000 \\
\end{array}$ & $\begin{array}{l}0.660 \\
0.000\end{array}$ & $\begin{array}{l}1 \\
- \\
\end{array}$ & $\begin{array}{l}0.768 \\
0.000 \\
\end{array}$ & $\begin{array}{l}0.281 \\
0.007\end{array}$ \\
\hline Lawton test & $\begin{array}{l}R \text { value } \\
p \text { value }\end{array}$ & $\begin{array}{c}-0.758 \\
0.000\end{array}$ & $\begin{array}{l}0.683 \\
0.000\end{array}$ & $\begin{array}{l}0.768 \\
0.000\end{array}$ & $\begin{array}{l}1 \\
-\end{array}$ & $\begin{array}{l}0.245 \\
0.020\end{array}$ \\
\hline Vitamin D & $\begin{array}{l}R \text { value } \\
p \text { value }\end{array}$ & $\begin{array}{c}-0.259 \\
0.014\end{array}$ & $\begin{array}{l}0.262 \\
0.013\end{array}$ & $\begin{array}{l}0.281 \\
0.007\end{array}$ & $\begin{array}{l}0.245 \\
0.020\end{array}$ & $\begin{array}{l}1 \\
-\end{array}$ \\
\hline
\end{tabular}


time in seconds spent in completing the TUG test between the two groups. In the multivariate analysis, the factors that were independently associated with mortality were male gender $(p=0.016)$ and Lobo test score $(p=0.002)$, respectively (data not shown).

\section{Final Phase}

A total of 90 patients were enrolled in the final phase (Table 1). When compared to the initial phase, no statistically significant differences were observed with regards to demographic and biochemistry values. In addition, no significant differences were observed with regards to biochemistry values between fallers and non-fallers during the final phase. With regards to comorbidities, hypertension, diabetes and rheumatological diseases were the most prevalent. The presence of falls was not significantly higher in individuals who presented some of the most frequent comorbidities (data not shown).

With regards to functional evaluation tests, there was a significantly lower score on Lobo and Barthel tests among fallers vs non-fallers (Table 2). As for TUG test, when individuals were grouped according to the time required to conduct the test, and using the cut-off point of 25 seconds, it was observed that the frequency of falls was significantly higher in those that required longer time to conduct the test $(p=0.039)$. The TUG cut-off value of 25 seconds had a sensitivity of 0.522 and a specificity of 0.746 , respectively (Figure 1 ).

With regards to drug treatments, the mean number of drugs used was $6 \pm 4$ (range $=0-19$ ). No statistically significant differences were observed between fallers and non-fallers as to type or number of treatments received (falls: mean treatments: $7.2 \pm 3.6$ vs no falls: $5.8 \pm 3.4, p=0.109$ ).

\section{Functional Evaluation Tests and Vitamin D}

Forty-seven (52.2\%) individuals had low level vitamin D concentrations $(<20 \mathrm{ng} / \mathrm{dL})$ during the final phase. A positive significant correlation between the serum concentration of vitamin D and the scores obtained in the Lobo, Lawton-Brody and Barthel tests and a negative correlation with the time in seconds required to complete the TUG test was observed (Table 3).

\section{Initial Vs Final Phase}

\section{Falls}

Only 14 individuals (15.5\%) did not refer any fall during any of the two phases of the study. A total of 53 (79.1\%) individuals that experienced falls during the baseline phase of the study did not experience any fall during the final phase of the study. Only five individuals (21.1\%) reported falls during both study phases. The factors associated with the absence of recurrence of falls in those who had previously presented them compared to those who had a fall recurrence were analyzed. For that, the following variables were compared: age, gender, comorbidities, functional evaluation tests' scores and biochemistry determinations. No statistically significant differences were observed between the two groups with regards to any of the above parameters (data not shown).

\section{Functional Evaluation Tests}

The mean values for the initial phase and final phase tests are shown in Table 4, detailing the data globally as well as in the two groups (individuals with and without falls in this final phase). The differences observed in each of the groups (with or without falls), except for TUG, were statistical significant. Both in the global group and in the two subgroups of individuals, during the four years between assessments, a significant deterioration occurred in each of the tests analyzed (Table 2).

\section{Multivariate Analysis of Risk Factors for Falls}

The only variable significantly associated with a risk of falls was Barthel test score $(p=0.006)$.

\section{Discussion}

The present study analyzed the prognostic factors of falls in seniors. The population studied was older and included more women compared to previous studies $(22,23)$. The frequency of falls was higher during the initial phase compared to the final phase. In addition, the frequency of falls observed during the final phase was significantly inferior to that reported by Rodriguez Molinero et al. (6) in a previous study conducted in Spain (50\%). It could be assumed that the subjects participating

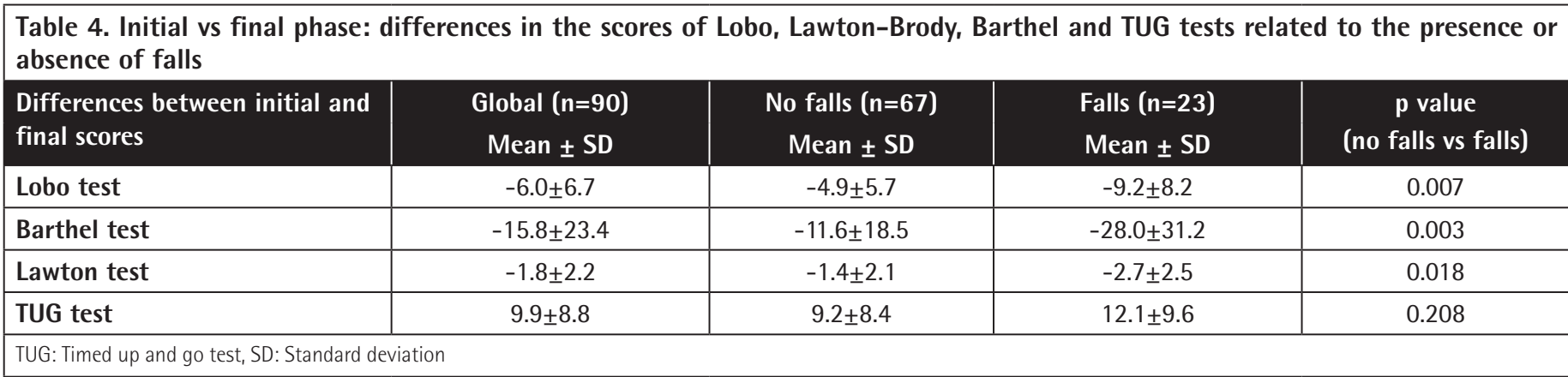


in the final phase represent a subgroup of individuals with better functional status or they protected themselves better after having experienced prior falls.

Baseline comorbidities included hypertension, diabetes mellitus and rheumatic diseases. However, unlike in other studies, their presence was not associated with an increased risk of falls in any of the two phases studied, nor there was a significant increase in the risk of falls associated with the use of drug treatments that favor their appearance $(4,24,25)$. The analytical profile of the participants was within normal range. Different alterations may have been associated with falls; however, no meaningful association was found. In addition, low vitamin D concentration was not associated with a higher risk of falls, although more than $50 \%$ of the participants showed a vitamin D deficit. The efficacy of vitamin D supplements to reduce risk of falls in individuals with low vitamin $D$ levels has been previously shown (26). It is possible, as Bromfield et al. (27) argues, that it is not the underlying diseases or the treatment itself but the existence of a fragility criterion.

In the initial phase of the study, the parameters that were significantly associated with the presence of falls were a higher concentration of hemoglobin and a higher score in Lobo and Barthel tests. These findings are seemingly paradoxical. It could be justified given that those patients who have a cognitive deterioration or less capacity for the basic activities of the daily life or a certain degree of anemia move less, and therefore require greater care, thus reducing therefore the risk of fall. One aspect to emphasize is the analysis of the evolution during the in between phases period. While no significant analytical modifications were observed, however, a significant deterioration of the cognitive, functional and TUG tests was detected. This scenario has been previously described by several authors, who explain the worsening of the functional evaluation tests with the "limited time mechanism" theory, that is, the decrease in the speed with which cognitive processing operations can be executed influences the functionality or autonomy for the basic and instrumental activities of daily life (28-30).

Finally, the different parameters, including the presence of falls, present in the initial phase on the mortality occurring between the two periods were analyzed. Mortality during the four years between the two phases was $43.7 \%$, being the causes of the death expected in this age group (cardio-or brain-vascular disease, neoplasms and dementias). The factors associated with greater mortality were male gender and a lower score in the Lobo test, confirming the results of previous studies (31-34). In the present study the causes of death were mainly vascular diseases and neoplasms, and therefore, there is no clear explanation that justifies the relationship previously mentioned.
The results in the final phase of the study showed a significantly higher incidence of falls associated with a lower score of the Lobo and Barthel tests, as well as with the differences in the scores in Lobo, Barthel and Lawton-Brody tests reported between the initial and final phases. It can therefore be concluded that in real life the cognitive and functional tests are the ones associated with the risk of falls in senior population and not so much the comorbidities, treatments received or analytical alterations. Several studies confirm that cognitive impairment, associated with an altered result in the Lobo test, and functional dependency, measured by the Barthel and Lawton-Brody tests, are key predisposing factors for the emergence of falls $(35,36)$.

One of the specific aims of the present study was to establish a cut off value of TUG that would identify the population with a greater risk of fall. In the initial phase of the study, the time to perform the TUG test did not differentiate those individuals who fell from those who did not. Only in the final phase a TUG cut off value of 25 seconds, that differentiated those who fell from those who did not, was established. The cut off value ranged from 12 to 16 seconds in prior studies $(37,38)$. The results of the TUG test showed a negative correlation with Lobo, Barthel and Lawton-Brody tests. While the correlation with the latter two was as expected (lower speed in exercise, less capacity for instrumental and even basic activities of daily life), the relationship with Lobo test was less obvious. However, there are studies in the literature that analyzed the relationship between these parameters and have shown that, at least partially, alterations in cognitive tests are correlated with alterations in the speed or variability of gait $(39,40)$.

\section{Study Limitations}

There are some limitations that should be mentioned. First, the number of patients that participated in the final phase is small (90 patients), that is, $36 \%$ of the initial sample, but it is also important to highlight that, none of the deaths during the in-between period (108 patients, 48\%), were due to complications related to a fall. Second, the results might have been affected by recall bias (fall history was obtained using a questionnaire) as well as selection bias (participants may have had a stronger interest in learning about their risk of fall compared to their peers who did not choose to participate). In addition, all subjects were recruited from a single independent living community in the Southern region of Spain, so it may be difficult to generalize our results to older adults with different characteristics or from other countries.

\section{Conclusion}

It can be concluded that the predictive factors of falls in individuals $>80$ years of age are mainly those that evaluate cognitive ability and functional activities. Moreover, the 
evaluation of the cognitive status by a simple test like the Lobo test contributes to evaluate their vital prognoses.

\section{Ethics}

Ethics Committee Approval: The study was conducted in Unidad de Gestión Clínica "La Laguna", Cádiz, Spain and was approved by the relevant health authorities and ethic committees (approval number: $\mathrm{CA}^{\prime} 80^{\circ}$ )

Informed Consent: Informed consent was obtained.

Peer-review: Externally peer-reviewed.

\section{Authorship Contributions}

Concept: J.B., J.M.I., S.P., J.A.G., Design: J.B., J.M.I., S.P., J.A.G., Data Collection or Processing: J.B., J.M.I., S.P., J.A.G., Analysis or Interpretation: J.B., J.M.I., S.P., J.A.G., Literature Search: J.B., J.M.I., S.P., J.A.G., Writing: J.B., J.M.I., S.P., J.A.G.

Conflict of Interest: No conflict of interest was declared by the authors.

Financial Disclosure: The authors declared that this study received no financial support.

\section{References}

1. Formiga F. Las caídas: un síndrome geriátrico por excelencia. Rev. Esp Geriatr Gerontol 2009;44:299-300.

2. López Martín I. Petidier Torregrosa, R. Geriatria y Atención Primaria de Salud: Caídas, en Guillen Llera, F. Sindromes y cuidados en el paciente geriátrico. Elsevier, 2a ed. Madrid 2008; pp. 117-131.

3. Lázaro del Nogal, M. Inestabilidad y Caídas en "Geriatría en Atención Primaria" Ribera Casado JM, et al eds. Ed. Biblioteca Aula Médica, 4a edición, Madrid 2008; pp. 243-254.

4. Mesa Lampré MP. Factores de riesgo de caídas en Evaluación del anciano con caídas, Documento del Grupo de Trabajo de Caídas de la Sociedad Española de Geriatría y Gerontología. Madrid 2011;pp. 17-36.

5. Marañón Fernández $E$, Mesas Sotos $R$, en Guillen Llera, F. Sindromes y cuidados en el paciente geriátrico. Elsevier, 2a edición, Madrid 2008; pp.497-512.

6. Rodriguez Molinero A, Narvaiza L, Gálvez-Barrón C, de la Cruz JJ, Ruiz J, Gonzalo N, Valldosera E, Yuste A. Caídas en la población anciana española: incidencia, consecuencias y factores de riesgo. Rev. Esp Geriatr Gerontol 2015;50:274-280.

7. Ribera Casado JM. Caídas y edad avanzada, ¿un problema médico? Med Clin 2004; 122:180-181.

8. Benitez J, Bellanco P. Avances en el estudio de las caídas en mayores. Análisis del punto de corte de Timed get Up and Go. Eur J Health Research 2015;1:15-25

9. Duaso $E$, Casas $A$, Formiga $F$, Lázaro Del Nogal $M$, Salvà $A$, Marcellán $T$, Navarro C. Unidades de prevención de caídas y fracturas osteoporóticas. Propuesta del Grupo de Osteoporosis, Caídas y Fracturas de la Sociedad Española de Geriatría y Gerontología. Rev Esp Geriatr Gerontol 2011;46:268274.

10. AGS/BGS clinical practice guideline: prevention of falls in older persons. In: www.alabmed.com/uploadfile/2014/0504/20140504033204923.pdf, accessed Feb 20,2019
11. Flores Ruano T, Cruz Jentoft A, González Montalvo JI, López Soto A, Abizanda Soler. Herramientas de valoración geriátrica en servicios de Geriatría. Rev Esp Geriatr Gerontol 2014;49:235-242.

12. Cid-Ruzafa J, Damián-Moreno J. Valoración de la discapacidad física: el indice de Barthel. Rev Esp Salud Pública 1997;71:127-137.

13. Díaz Pelegrina A, Cabrera-Martos I, López-Torres I, Rodriguez-Torres J, Valenza MC. Efectos del estado cognitivo sobre las alteraciones del equilibrio y la marcha en ancianos institucionalizados. Rev Esp Geriatr Gerontol 2016;51:88-91.

14. Podsiadlo D, Richardson S. The "Up \& Go" timed: a basic functional mobility test for frail elderly people. J Am Geriatr Soc 1991;39:142-148.

15. Tinetti ME, Speechley M, Ginter SF. Risk factors for fall among elderly persons living in the community. N Eng J Med 1988;319:1701-1717.

16. Roqueta $C$, De Jaime $E$, Miralles $R$, Cervera AM. Experiencia en la evaluación del riesgo de caídas. Comparación entre el test Tinetti y el Timed get Up \& Go. Rev Esp Geriatr Gerontol 2007;42:319-327.

17. Lázaro del Nogal M, González-Ramirez A, Palomo-Iloro A. Evaluación del riesgo de caídas. Protocolos de valoración clínica. Rev Esp Geriatr Gerontol 2005;40:54-63.

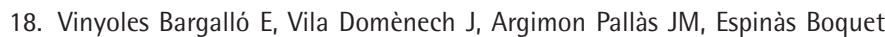
J, Abos Pueyo T, Limón Ramírez E; Los investigadores del proyecto Cuído. Concordance among Mini-Examen Cognoscitivo and Mini-Mental State Examination in cognitive impairment screening. Aten Primaria 2002;30:513.

19. Lawton MP, Brody EM. Assessment of older people: Self-maintaining and instrumental activities of daily living. The Gerontologist 1969;9:179-186.

20. Mahoney Fl. Functional evaluation: the Barthel index. Maryland State Med J 1965;14:61-65.

21. Bernaola-Sagardui I. Validation of the Barthel Index in the Spanish population. Aging Clin Exp Res. 2018;30:489-497.

22. Formiga F, Ruiz D, López Soto A, Duaso E, Chivite D, Perez-Castejon JM. Circunstancias asociadas a las caídas responsables de fractura de fémur en pacientes ancianos. Diferencias por grupo de edad y género. Rev Clin Esp 2006:206:314-318.

23. Rubenstein L Z, Josephson KR. Falls and their prevention in elderly people: what does the evidence show? Med Clin N Am 2006;90:807-824.

24. Espaulella, M. Tratamiento para la HTA y riesgo de caídas. Sociedad Catalana de Geriatria y Gerontología. http://scgig.cat/tratamiento-para-la-hta-yriesgo-de-caidas-por-mariona-espaulella, accesses Feb 14, 2019

25. Yang Y, Hu X, Zhang Q, Zou R. Diabetes mellitus and risk of falls in older adults: a systematic review and meta-analysis. Age Aging 2016;45:761-767.

26. Costa Gameiro D. Efecto de la Vitamina D sobre el rendimiento físico en ancianos frágiles institucionalizados. Tesis Doctoral Universidad de Salamanca 2015.

27. Bromfield SG, Ngameni CA, Colantonio LD, Bowling CB, Shimbo $D$, Reynolds K, Safford MM, Banach M, Toth PP, Muntner P. Blood pressure, antihypertensive polypharmacy, frailty and risk of serious injury from falls in adults treated with hypertension. Hypertension 2017;70:259-266.

28. Martos Martín A. Variables medidoras en la relación entre deterioro cognitivo y la capacidad funcional en personas mayores, Tesis doctoral Universidad de Granada, 2005.

29. Salthaouse TA. The processing-speed theory of adult age differences in cognition. Psychol Rev 1996;103:403-428.

30. Salthaouse TA. Aging and measures of processing speed. Biol Psychol 2000;54:35-54.

31. Palmer K, Wang HX, Backman L, Winblad B, Fratiglioni L. Differential evolution of cognitive impairment in nondemented older persons: results from the Kungsholmen Project. Am J Psychiatry 2002;159:436-442. 
32. Ingles JL, Fisk JD, Merry HR, Rockwood K. Five-year outcomes for dementia defined solely by neuropsychological test performance. Neuroepidemiology 2003;22:172-178.

33. Wilson RS, Aggarwal NT, Barnes LL, Bienias JL, Mendes de Leon CF, Evans DA. Biracial population study of mortality in mild cognitive impairment and Alzheimer disease. Arch Neurol 2009;66:767-772.

34. Guehne U, Luck T, Busse A, Angermeyer MC, Riedel-Heller SG. Mortality in individuals with mild cognitive impairment. Results of the Leipzig Longitudinal Study of the Aged (LEILA75+). Neuroepidemiology 2007;29:226-234.

35. Ferrer A, Formiga F, Plana Ripoll 0, Tobella MA, Gil A, Pujol R; Octabaix Study Group. Risk of falls in 85-year old is associated with functional and cognitive status: The Octabaix Study. Arch Gerontol Geriatr 2011;54:352356.

36. Bath PA, Morgan K. Differential risk factor profiles for indoor and outdoor falls in older people living at home in Nottingham, UK. Eur J Epidemiol 1999;15:65-73.
37. Marcos Alfieri F, Abril Carreres MA, Garreta Figueras R, Rizzo Battistella L. Comparación del tiempo de ejecución del test Timed up and Go (TUG) en ancianos con y sin antecedentes de caidas. Rev Esp Geriatr Gerontol 2010;45:174-175.

38. Barry E, Galvin R, Keohg C, Horgan F, Fahey T. Is the Timed Up and Go test a useful predictor of risk of falls in community dwelling older adults: a systematic review and meta-analysis. BMC Geriatrics 2014;14:14.

39. Holtzer R, Verghese J, Xue X, Lipton RB. Cognitive processes related to gait velocity: results from the Einstein Aging Study. Neuropsychology 2006;20:215-223.

40. Tian 0, Chastan N, Bair WN, Resnick SM, Ferrucci L, Studenski SA. The brain map of gait variability in aging, cognitive Impairment and dementia. A systematic review. Neurosci Biobehav Rev 2017;74:149-162. 